\title{
Vida Saludable para Personas de Edad: Los Suplementos Dietéticos ${ }^{1}$
}

\section{Jennifer Hillan ${ }^{2}$}

\section{TIV Los suplementos dietéticos incluyen a las vitaminas, los Elder Nutrition and Food satety minerales, las hierbas medicinales y otras sustancias. Si usted toma cualquiera de estos productos, siga los siguientes consejos que le ayudarán a usarlos de una manera segura.}

\section{Consulte con su médico o}

\section{farmacéutico}

Pregúntele antes de tomar cualquier tipo de suplemento por primera vez. Su médico le puede indicar:

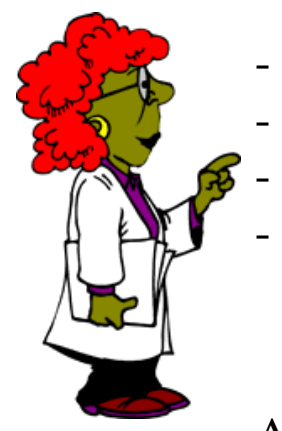

- cuanto debe tomar

- cuando debe tomarlo

- posibles efectos secundarios

- posibles interacciones con otros suplementos u otras medicinas

Avise a su médico si siente algún síntoma después de tomar un suplemento. Deje de tomarlo y vea si los síntomas desaparecen.

\section{Compre productos que sean de confianza}

Busque productos que lleven el sello del US pharmacopeia (USP).

Este sello garantiza que el producto a pasado ciertos controles de calidad.

\section{Compruebe la fecha de expiración}

Elija productos que estén

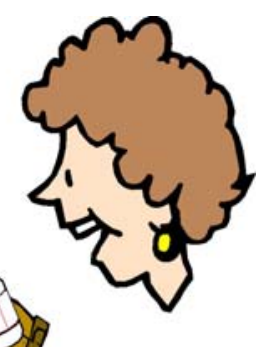

claramente marcados con una fecha de expiración. Asegúrese de que la fecha de expiración no sea cercana para que le dé tiempo a usar la totalidad del producto antes de que expire.

\section{¡Preste mucha atención!}

Los productos que incluyen en su etiqueta la palabra "natural” u "orgánico” no siempre son productos de confianza. Estas palabras pueden ser un truco publicitario para hacerle pensar que se trata de un buen producto.

Sea cuidadoso con productos que dicen ser “una cura instantánea”. Por norma, si suena demasiado bien para que sea verdad, probablemente no lo sea.

1. This is document FCS 8623-SPAN, one in a series of the Department of Family, Youth and Community Sciences, Florida Cooperative Extension Service, Institute of Food and Agricultural, Sciences, University of Florida, Gainesville, FL 32611. Publication date: March 2004. The English version of this Spanish language leaflet is Healthy Living for Elders: Tips for Taking Dietary Supplements. This leaflet was developed with funding from the Florida Department of Elder Affiars in partnership with state, county , and local agencies. Please visit the EDIS Web site at http://edis.ifas.ufl.edu

2. Jennifer Hillan, MSH, RD, LD/N, former ENAFS nutrition educator/trainer, Department of Family, Youth and Community Sciences, Institute of Food and Agricultural Sciences, University of Florida, Gainesville, FL 32611. English version reviewed by Linda B. Bobroff, PhD, RD, LD/N, professor, University of Florida, Translated by Sergio Romero, MS, ATC, University of Florida. Translation reviewed by Isabel Valentín-Oquendo, MS, RD, former FNP curriculum coordinator, University of Florida. 